\title{
Spotlight on cellular lipid binding proteins
}

\author{
Citation for published version (APA):
}

Glatz, J. F. C. (2015). Spotlight on cellular lipid binding proteins. Prostaglandins Leukotrienes and Essential Fatty Acids, 93, 1-1. https://doi.org/10.1016/j.plefa.2014.12.007

Document status and date:

Published: 01/02/2015

DOI:

10.1016/j.plefa.2014.12.007

Document Version:

Publisher's PDF, also known as Version of record

Document license:
Taverne

\section{Please check the document version of this publication:}

- A submitted manuscript is the version of the article upon submission and before peer-review. There can be important differences between the submitted version and the official published version of record.

People interested in the research are advised to contact the author for the final version of the publication, or visit the DOI to the publisher's website.

- The final author version and the galley proof are versions of the publication after peer review.

- The final published version features the final layout of the paper including the volume, issue and page numbers.

Link to publication

\footnotetext{
General rights rights.

- You may freely distribute the URL identifying the publication in the public portal. please follow below link for the End User Agreement:

www.umlib.nl/taverne-license

Take down policy

If you believe that this document breaches copyright please contact us at:

repository@maastrichtuniversity.nl

providing details and we will investigate your claim.
}

Copyright and moral rights for the publications made accessible in the public portal are retained by the authors and/or other copyright owners and it is a condition of accessing publications that users recognise and abide by the legal requirements associated with these

- Users may download and print one copy of any publication from the public portal for the purpose of private study or research.

- You may not further distribute the material or use it for any profit-making activity or commercial gain

If the publication is distributed under the terms of Article $25 \mathrm{fa}$ of the Dutch Copyright Act, indicated by the "Taverne" license above, 


\section{Editorial}

\section{Spotlight on cellular lipid binding proteins}

Specific cellular proteins capable of reversibly and non-covalently associating with lipids, and therefore designated as lipid binding proteins or lipid chaperones, are established to serve a broad range of physiological functions in various tissues. In general, these cellular lipid binding proteins determine the bio-availability of their ligands, thereby markedly influencing the subsequent processing, utilization, and/or signaling effect of lipids. The family of intracellular lipid binding proteins comprises a.o. cytoplasmic fatty acid-binding proteins (FABPs), retinol/retinoic acid binding proteins, and oxysterol binding protein. Membrane-associated lipid binding proteins include a.o. the multifunctional protein CD36 and a group of so-called fatty acid transport proteins (FATPs). Together, these membrane-associated and cytoplasmic proteins facilitate the transport of lipids across biological membranes and within the aqueous cytoplasm, and by this property influence the role of lipids as vital components of many biological processes and as crucial parameter in the pathogenesis of numerous common diseases. In addition, pharmacological agents that compete with lipid binding by these proteins will modify the function of cellular lipid binding proteins. In view of the occurrence of several tissue-specific types of lipid binding proteins, such agents may provide tissue-specific or cell type-specific control of metabolic regulation, lipid signaling pathways, and inflammatory responses. Now that the biological functions of cellular lipid binding proteins are getting better understood, examples of the feasibility of such pharmacological intervention strategy have become available.
Continued interest in the cellular lipid binding proteins has led to the organization of a series of international conferences specifically devoted to this topic. The 8th International Conference on Lipid Binding Proteins was held in La Plata, Argentina, on November 3-6, 2013, and was organized by Betina Córsico and Horacio Garda and her team from the University of La Plata. As with the previous meetings, this 8th conference has opened new research venues in a field that has become of increasing importance for the understanding of various chronic diseases and their treatments. The current issue of Prostaglandins, Leukotrienes and Essential Fatty Acids contains a collection of selected articles based on the lectures and posters presented during the conference. These articles combined provide insight into our current understanding of the significance of cellular lipid binding proteins for the functioning of the cell under normal and pathophysiological conditions.

Jan F.C. Glatz

Department of Genetics \& Cell Biology, Cardiovascular Research Institute Maastricht (CARIM), Maastricht University, Maastricht, The Netherlands E-mail address: glatz@maastrichtuniversity.nl 